\title{
Research Square \\ Environmental food and cognitive enrichment: a study of well-being for large captive felids at the Zoo of Goiânia
}

Marina Rangel ( $\square$ madininh4@hotmail.com )

Pontifícia Universidade Católica de Goiás

Nelson Da Silva Júnior

Pontifícia Universidade Católica de Goiás

\section{Research Article}

Keywords: Environmental enrichment, environmental sciences, health, felines, well-being, zoo, urban park

Posted Date: April 15th, 2021

DOI: https://doi.org/10.21203/rs.3.rs-395609/v1

License: (c) (i) This work is licensed under a Creative Commons Attribution 4.0 International License.

Read Full License 


\title{
Environmental food and cognitive enrichment: a study of well-being for large captive felids at the Zoo of Goiânia
}

\author{
Marina Cronemberger Rangel ${ }^{1}$, Nelson Jorge da Silva Jr²
}

${ }^{1}$ Pontífica Universidade Católica de Goiás - Brasil.

${ }^{2}$ Pontifica Universidade Católica de Goiás - Brasil.

*E-mail para correspondência:

'madininb4@,hotmail.com ;'nelson.jorge.silvajn@gmail.com

\section{RESUMO \\ Enriquecimento ambiental alimentar e cognitivo: um estudo de bem-estar para grandes felinos cativos no Zoológico de Goiânia.}

Com o intuito de promover a pesquisa e a conservação das espécies, os zoológicos tendem a promover uma modernização desse sistema, como a inserção de recintos maiores e adequados, enriquecimentos ambientais, e sobretudo a conservação das espécies. Os objetivos principais deste trabalho foram: promover enriquecimento ambiental alimentar e cognitivo aos grandes felinos, além de discutir a validade deste modelo de enriquecimento. Os animais de estudo foram 12 animais: quatro tigres (Panthera tigris), três suçuaranas (Puma concolor), três onças-pintadas (Panthera onca) e dois leões (Panthera leo). Utilizamos um etograma base para análise dos comportamentos, no qual se deu a análise de comportamentos específicos: pacing e inatividade. Com o método de observação animal focal, e usando o método de enriquecimento "caixa surpresa", que consistia em pedaços de carne dentro de caixas de papelão, os resultados estatísticos obtidos indicaram que o enriquecimento aumentou o comportamento social, repouso e fisiológico, e diminuiu o pacing e a inatividade. Cada espécie reagiu de uma forma específica aos enriquecimentos, sendo notados melhores resultado com o grupo Panthera onca, seguidos do grupo Panthera leo, Panthera tigris e Puma concolor, respectivamente. A teoria do uso do enriquecimento ambiental foi comprovada e comparada com outros trabalhos realizados semelhantes a esse.

Palavras-chave: Enriquecimento ambiental, ciências ambientais, saúde, felinos, bem-estar, zoológico, parque urbano.

\begin{abstract}
Environmental food and cognitive enrichment: a study of well-being for large captive cats at the Zoo of Goiânia.

In order to promote research and conservation of species, zoos tend to promote the modernization of this system, such as the insertion of larger and adequate enclosures, environmental enrichments, and above all the conservation of species. The main objectives of this work were: to promote environmental food and cognitive enrichment for big cats, in addition to discussing the validity of this enrichment model. The study animals were 12 animals: four tigers (Panthera tigris), three puma (Puma concolor), three jaguars (Panthera onca) and two lions (Panthera leo). We used a basic ethogram for the analysis of behaviors, in which there was an analysis of specific behavior: rhythm and inactivity. With the focal animal observation method, and using the "surprise box" enrichment method, which consisted of pieces of meat inside cardboard boxes, the statistical results obtained indicated that enrichment increased social, rest and physiological behavior, and slowed down and downtime. Each species reacted in a specific way to enrichments, with better results being noticed with the Panthera onca group, followed by the Panthera leo, Panthera tigris and Puma concolor group, respectively. The theory of the use of environmental enrichment was proven and compared with other works similar to this one.
\end{abstract}

Keywords: Environmental enrichment, environmental sciences, health, felines, well-being, zoo, urban park. 


\section{Introduction}

The concept of zoos in modern times has been questioned and rethought worldwide. Taking into account that zoos have existed for thousands of years, coming from a history of use by royalty and nobles, with the sole purpose of showing collections of exotic animals and no concern for the welfare of these animals, with the use of a concrete enclosure and iron bars, with no areas for the animal to hide or isolate itself from visitation, this type of zoo management no longer exists. The existence of collections of wild animals in captivity for exclusive public entertainment is no longer supported, either ethically or morally (DIAS, 2003).

In order to mainly promote research and conservation of species, modern zoos tend to promote a modernization of this system. With the insertion of enclosures as close as possible to the reality of the animal, environmental enrichment appropriate to each species, correct training of zoo staff for better handling of captive animals, and especially the conservation of species.

The proposal for environmental enrichment for animals in captivity is a modern proposal for zoos, which consists of creating a more complex and interactive environment for animals, promoting challenges and novelties that simulate situations that would occur in nature, offering an opportunity of choice to the animal kept in captivity. This allows the expression of natural and species-specific behaviors.

The present work evaluates the proposal for environmental enrichment, which consists of structural change and improvement of the enclosures, in addition to the management of animals, always aiming to improve the quality of life for the large captive cats in the Parque Zoológico de Goiânia (PZG). It was carried out from January 2018 to June 2019, for the analysis of well-being and influence of behaviors in a direct relationship to improve human exposure, as one of the fundamental playful attributions of a zoo. 


\section{Material and Methods}

\section{Study area}

The Zoological Park of Goiânia has been inserted in an urban area since the beginning of the construction of the city of Goiânia, being one of the first public green parks in the city, known as Parque Lago das Rosas.

\section{Focal animals}

The animals studied for this work are composed of 12 large cats, being tigers, of which two males (Kael and Tigrão) and two females (Paula and Paola) (Panthera tigris), sussuaranas, of which two males (Gordão and Macho) and a female (Tronchinha) (Puma concolor), jaguars, of which two males (Pacato and Tony) and a female (Juma) (Panthera onca) and lions, of which a female (Ana) and a male (Lailos) ( Panthera leo).

\section{Food}

The big cats are fed six times a week at the Parque Zoológico de Goiânia, from Monday to Saturday, once a day, always at 1:30 pm. There was no change in the amount of food offered during work.

\section{Methodological processes}

\section{Enrichment method}

Surprise box - Pieces of meat (supplied by the zoo) were inserted into cardboard boxes, thus stimulating foraging, with cognitive enrichment for animals to solve the problem of opening the box and obtaining food, and food enrichment for modifying the way of providing the meal.

\section{Behavior analysis}

For the behavioral analysis, the focal animal observation method (Focal Sampling) was used, this method consists of sampling the behaviors of one individual at a time, for a standardized period of time. For such analysis, an ethogram table was used (STANTON, 2015). Only those that would be most relevant for the 
analysis of improved well-being in relation to environmental enrichment were selected: rest / stopped (RP), olfactory (EO), social (S), stereotyped (EC) and physiological (F).

The observation took place on alternate days, counting four days a week, from Monday to Thursday, with only one species being observed per day and alternating their order per week. In the month, therefore, 16 observations were made. As each species was observed only once a week, in the month each species was analyzed four times. The first two months were for observation before enrichment, followed by two months of enrichment, and ending with two months after withdrawal of environmental enrichment. In the end totaling six months of observations from all the felids.

\section{Data analysis}

The analyzes were performed with the aid of the statistical package SPSS, 23. The distribution of the couples according to the groups of felines was carried out by means of absolute (n) and relative (\%) frequency using the Posthoc Chi-square test . The normality of the data was verified using the Shapiro-Wilk test. The evolution of behaviors according to the species and groups of cats was tested using the Friedman test followed by the Posthoc analysis by Nemenyi. The analysis of the canonical discriminating function was used in order to verify which of the behaviors had the greatest contribution in the investigation of environmental enrichment. The analysis of the factor variance (ANOVA-Factorial) was also carried out using a Generalized Linear Model (MLG) with the behaviors that had the greatest contribution in the analysis of the discriminant function. Significant comparisons were followed by Tukey's multiple comparisons analysis. In all analyzes, a significance level of $5 \%(\mathrm{p}<0.05)$ was adopted.

\section{Ethical aspects}

This project was submitted and authorized by the Ethics Committee on the Use of Animals of PUC Goiás (CEUA), document $n^{\circ} 7339180418$, for the analysis of the big cats in the Parque Zoológico de Goiânia.

The experiment is done in accordance with the relevant national and international guidelines. 


\section{Results}

It was proved that in all groups there were significant changes in social behavior (S). Regarding the Panthera leo group, it is noted that in the 'before' $(0.00 \pm$ $0.00)$ and 'after' $(0.00 \pm 0.00)$ phase of enrichment, no social behaviors were recorded, which consist of interaction of the animal with the box, only in the 'during' phase (1.63 \pm 1.02) was expressed and analyzed. Still regarding the Panthera leo group, it is evident that the olfactory exploration (EO) behavior also had a significant value, in which it obtained a greater expression of the behavior in the 'during' phase $(1.75 \pm 1.06)$ and that in the 'after' phase this increase was slightly reduced $(0.81 \pm 0.83)$, but remains more expressive than in the 'before' phase $(0.25 \pm 0.45)$ (Table 1$)$.

Significant changes were also evidenced with the Friedman test in the olfactory exploration (EO) behavior in the 'before', 'during' and 'after' for the species Panthera leo, Panthera onca and Puma concolor, which obtained greater exploration stimulus due to enrichment. It is important to note that the exploitation of the enclosure by the felines was already verified, however with the stimuli these explorations became more evident and frequent (Table 1).

With the Panthera onca group, significant changes were observed in relation to various behaviors, in this case: vocalization $(\mathrm{V})(\mathrm{p}=0.05)$, olfactory exploration (OF) (p <0.001), agonism (A) $(\mathrm{p}=0.05)$, social $(\mathrm{S})(\mathrm{p}<0.001)$, stereotyped $(\mathrm{CE})(\mathrm{p}=0.01)$ and physiological $(\mathrm{F})(\mathrm{p}=0.003)$ behavior. These results show us that the Panthera onca group was the most beneficially influenced by enrichments, as these observed changes indicate a change in behaviors for greater well-being, expression of natural behaviors and, consequently, the quality of life of the animal (Table 1).

For the Panthera tigris group, significant changes were found in physiological actions $(\mathrm{F})(\mathrm{p}=0.01)$ and in social behavior $(\mathrm{S})(\mathrm{p}<0.001)$. In relation to social behavior, in the 'before' some frequencies of behavior expressions are observed $(0.06 \pm 0.25)$, however in the 'during' $(0.75 \pm 0.95)$ a greater expression is already noticed, and in the after enrichment $(0.00 \pm 0.00)$ this behavior is no longer evident (Table 1).

In contrast, with the Puma concolor group there were two behaviors that were not expressed in any phase (na), which was vocalization (V) and agonism (A). However, it is evident that there was an improvement with results for the olfactory (EO) $(\mathrm{p}<0.001)$ and social $(\mathrm{S})(\mathrm{p}=0.02)$ behaviors. For EO it is shown in the table that in the 'before' $(0.50 \pm 0.93)$ there were already explorations of the enclosure, in the 'during' (2.21 
\pm 1.41 ) with the application of the surprise box an increase is shown of this exploitation, already in the 'after' $(1.33 \pm 1.09)$ it is noted that the exploitation continues to be carried out by the sussuaranas, however relatively less than in the previous phase (Table 1).

As for the social behavior (S) of the Puma concolor group, in the 'before' period $(0.00 \pm$ $0.00)$ there is no expression of behavior, only in the 'during' $(0.54 \pm 0.98)$ and in the ' after '(0.42 \pm 1.14$)$ (Table 1$)$.

According to the contribution of each behavior and which were more relevant to the analysis, it was verified with the analysis of the coefficient of the discriminant function that the social behavior (S) (0.84) obtained the most significant result and had the greatest contribution to behavior analysis, followed by rest / stopped (PR) (0.49) and stereotyped behavior (EC) (0.49), respectively (Table 2).

From the analysis of the discriminant function, it was found that the 1st axis of the function was able to explain $70.9 \%$ of the variation, while the second axis $33.0 \%$. There was a significant separation in the scores associated with the different groups. Regarding the 1st axis of the discriminant function, it was found that the groups Panthera onca and Panthera leo, have an inverse relationship between the groups Puma concolor and Panthera tigris. Those who were closest, such as Puma concolor and Panthera tigris, had the most similar behaviors, differently for Panthera onca and Panthera leo indicated by the groups' centroids. The total adjustment of the discriminant model, that is, the percentage of variation found in the behaviors of the groups explained was 19\% (Figure 1).

Regarding the variable social behavior (S), it was found that in all species of felines different behaviors were observed from each other, that is, each species presented a different pattern in relation to social behavior. Regarding the $\mathrm{p}$ of the origin of environmental enrichment, it is observed that there is a significant variation, while the comparison of the groups in relation to environmental enrichment indicates that the effect was not similar in the four groups (Table 3).

A significant difference in social behavior (S) was found when comparing the 'before', 'during' and 'after' of all species. A pattern is observed for the 'during' increase groups, and all have practically had a drop in 'after' behavior expression. With the exception of Puma concolor which obtained an absence of variation from 'during' to 'after' (Figure 2).

In relation to the variable stereotyped behavior (EC), a significant difference from the stereotyped behavior was found with the relation of origin of the 
groups, with the comparison 'before', 'during' and 'after'. There were no significant differences in relation to environmental enrichment, and the relationship between groups and environmental enrichment (Table 4).

It was found that the relationship of stereotyped behavior is different for each group. The Panthera tigris and Puma concolor groups were seen with a large increase in stereotyped behavior from 'before' to 'during', and a drop 'after' enrichment. In the Panthera leo group, the stereotyped behavior had a slight drop from 'before' to 'during', and soon 'after' the withdrawal of enrichment shows a great increase in this behavior. Finally, Panthera jaguar has a decrease in stereotyped behavior until 'during', however after the withdrawal of enrichment it is kept stable (Figure 3).

The only significant difference was in relation to environmental enrichment, that is, there is a significant difference in rest / stopped behavior, with the comparison 'before', 'during' and 'after' No significant differences were observed in relation to groups and the relationship groups with environmental enrichment (Table 5).

The groups obtained the results of similar resting / stopped behaviors, with the exception of Panthera leo, which the fall was constant. However, this small variation when performed the test, was not able to produce a significant variation (Figure $4)$. 


\section{Discussion}

In the present study, the use of environmental enrichment and its influence on the welfare behavior of large captive cats in the Parque Zoológico de Goiânia (PZG) were evaluated. It was possible to confirm the hypothesis that the use and management of environmental enrichment would bring benefits to animal welfare. The frequencies of some behaviors brought positive changes in relation to the later stage of enrichment, showing that the big cats of the PZG can still demonstrate natural behaviors and that stress in captivity can be avoided and relieved.

The use of environmental enrichment proved to be positive in improving the welfare of the animals that received it, demonstrating that this technique is efficient and that it should be applied routinely in zoos (YOUNG, 2003), being the same technique used in this work. However, prior to the study it was found that the use of $\mathrm{AE}$ with large cats was not a fixed routine, but sporadic in the PZG.

In this way, at the beginning of the study before using the AE, all the cats showed stereotyped behaviors in their filming, such as pacing and excessive inactivity, probably derived from the lack of stimulation in their enclosures and regarding the little built space of each one. one, disproportionate to their real area of living in nature. For example, in relation to the lion (Lailos), its enclosure in the PZG is $211.653 \mathrm{~m}^{2}$ of total area. In contrast, in nature the maintenance of territory is an essential aspect of success for male African lions (Panthera leo), ranging from $11.5 \mathrm{~km}^{2}$ to $1,002 \mathrm{~km}^{2}$ across southern Africa (DUNSTON, 2017), thus being a lion captive male in an area much smaller than his natural will behave with stereotype and stress.

In a study of the behavior of lions in relation to the space used in their enclosures in zoos in comparison with lions in open sanctuaries, it also showed that the theory that space is important to lions, in which subjects in enclosures tend to present greater expressions pacing, compared to lions living in sanctuaries with areas more compatible with their natural habitat (BABB, 2020).

By analyzing the behaviors and results of the Panthera leo group, considered a social species and tending to live in groups in nature, it can be explained that the significant results with olfactory exploration (EO) and social behavior (S) are intrinsically involved with all its behavioral ecology. Taking this premise into account, the captive lions in the PZG, after receiving the stimulus of enrichment, presented more 
actively these behaviors that would normally be expressed in the wild, being positive points for their well-being in captivity.

In a study by Dunston in Africa, it was analyzed whether lions in captivity after being reintroduced into the wild would express natural hunting and foraging behaviors. In the study the evidence suggests that, by moving lions to a reserve with greater space and greater access to prey, these groups of captive origin are able to establish and defend a territory, and to become independent again in nature (DUNSTON, 2017).

African lions (Panthera leo) are the only social felids that live in fusion-split groups, which can fragment into smaller subgroups (KOTZE, 2018). Staying in captivity in which they are alone, as in the case of the lion and lioness in separate enclosures, is likely to trigger various types of stereotyped behaviors, such as pacing or excessive inactivity, which were observed in the two lions of the PZG. The lion always after feeding also presented vocalization behaviors, which drew the attention of all visitors there at the PZG, but the vocalization was not affected by environmental enrichment in the present study. In another study of the behavior of African lions in a zoo in Peru, it was argued that it is possible that it is a way of demarcating territory or calling others of the same species (CORILLOCLLA; ALFRE-DO, 2018), for being alone in his enclosure.

As for tigers (Panthera tigris), during their analysis, it was possible to observe that from handling the filming preparation to the feeding schedule (which were done at the same time), they previously presented stress behaviors and, consequently, pacing, both in period 'before', as well as 'during' and 'after' the EA. With the exception of the tigress Paola, who was always calm and was receptive to keepers and filming, the other three individuals the degree of anxiety was clearly observed. These observed behaviors are in line with the work carried out by Veroneze (2020), in which he demonstrates that tigers are more reserved with the insertion of new items into the enclosure at first, getting used to it after a few days of insertion.

Comparing the results with other work carried out also with tigers in captivity in Moscow, it was found that there was an increase in foraging activities and a decrease in pacing after the insertion of enrichment, proving the theory that the use of EA is essential for your good -being in captivity (PODTURKIN, 2020).

The Panthera tigris group obtained significant results only in social (S) and physiological (F) behavior. We can talk about this behavior taking into account 
all its behavioral ecology, being solitary tigers in nature, extremely territorial, and often avoiding human contact. With the insertion of enrichment, the tigers Kael and Paola, who are in separate enclosures, but had a view of each other through bars, interacting better with enrichment only when they felt comfortable with the new object. Paola learned to open the box quickly, and showed interest in interacting with it from the first time, unlike Kael who remained without eating or interacting with the box, being necessary after the first filming with the EA to remove the boxes and serve Kael's food normally for him to eat. However, Kael observed Paola a lot in her enclosure, and it is possible to observe that she accepted the box better when she realized that the female did not reject her, that she was not a threat, and initiated the interaction with the EA and improvement in BEA were observed.

The tigers, Tigrão and Paula, who are allocated together in the same enclosure, had different results. Only the female interacted with the enrichment, the male was always extremely stressed, expressing agonist behaviors, pacing, besides showing discomfort with the new object inserted in his territory, in addition to the handling of the keepers when entering his enclosure. The social behavior involved interacting with the boxes, and the physiological behavior was observed after the interaction, where the tigers remained lying in a resting position and licking themselves after feeding.

Tigers are one of the most commonly exhibited species in the world: they breed well in captivity (BROWN, 2011), are tolerant of heat and cold (SHOEMAKER, 1997) and are among the charismatic megafauna thanks to their great potential to attract visitors to the zoo (BROWN, 2011; SKIBINS, POWELL, 2013). However, its territory area, with an average of $48.40 \mathrm{~km}^{2}$, cannot be reasonably supplied in captivity (BRENTON, BARROT, 2014; CLUBB, MASON, 2007), so the best alternative would be the EA to tigers in captivity, so that minimize the chance of damage to the expression of natural behaviors.

With the introduction of $\mathrm{AE}$ in the tigers' environment, an improvement in their social behaviors and a decrease in stereotyped behaviors was observed, which included in addition to eating the meat, interacting with the enrichment box and / or playing / biting the box. In the 'after' analysis phase, it was verified whether the welfare benefit remained, but with the withdrawal of the EA, the tigers returned to their previous stress levels and stereotyped behaviors. Thus, this demonstrates the efficiency of the stimuli and the change in obtaining food, which simulates prey hunting, improving their well-being in captivity. 
In relation to the Panthera onca group, the greatest number of significant results were obtained for the stimuli of environmental enrichment, being positive in relation to behaviors: vocalization (V), olfactory exploration (EO), agonism (A), social (S), stereotyped (EC) and physiological (F) behavior. The jaguar is a territorial animal and uses feces, urine and scratches on trees to define its living area. Of solitary habit, it interacts with other individuals of the species only in the reproductive period, being that a male can mate with several females (ONÇA-PINTADA, 2019).

In a study carried out by Veroneze (2020), it was analyzed that jaguars normally interact very well with the insertion of several different types of environmental enrichment in their enclosures, and in the case of the food and cognitive enrichment used in this work, they meet to the results found by Veroneze in his study on the behavior of jaguars in captivity.

This wide range of responses to stimuli may be influencing behavioral ecology, as we can mention the example of the jaguar couple Tony and Juma, who share the same enclosure. The two before the application of the EA had to feed separately, as Tony ate Juma's food, with the application of the EA the opposite was seen, Juma showed agonistic behaviors with Tony and kept him away from the food she found in the box and only allowed let him eat after she finished. It is likely that, Juma exhibited agonist behaviors due to the stimulus to his natural hunting behavior, and, therefore, his defense when conquered. However, after the two ate, behaviors of play and fun were observed, mainly expressed by Juma, who called Tony to play.

The male melanic jaguar (Pacato), who found himself alone in an enclosure, always exhibited playful behavior with the keepers, including during the assembly of the cameras, showing that he was comfortable with the analysis of his enclosure. He often demarcated the camera itself that was mounted in the cabling area, splashing jets of urine spray on it, perhaps as a way of delimiting its territorial space, even though it was receptive to human presence.

The jaguars were the most receptive to all the stimuli offered in the enclosures during the EA at the PZG, showing behaviors of anxiety when visualizing the boxes being assembled by the keepers in their enclosures. All three jaguars exhibited hunting behavior, jumping and attacking boxes, demonstrating behaviors that they would perform in the wild when hunting.

Pumas concolor have their peculiarities regarding the observed behaviors, presenting significant results in olfactory (EO) and social (S) exploration. Like 
cats in general, pumas are primarily nocturnal and twilight, with peaks of activity at dusk and dawn and with limited daytime activity (MAIA, 2009). During the enrichment that was during the day, little natural behavior was observed, besides one of the felines, the male Gordão, presenting problems in the hind legs of arthrosis, his locomotion was compromised and he remained most of the time lying down.

In an environmental enrichment study involving cougars, it was observed that animals that show nocturnal or twilight activity are unlikely to exhibit more active behavior during the morning and afternoon, especially if these animals have a milder natural climate and start to live in a very hot climate or vice versa (VERONEZE, FERNANDES, ALMEIDA, SILVA, BORLINI, 2020)

In a study carried out at the Campinas Zoo (MAIA, 2009) in relation to the behavior of the whispers showed that the amount of noise that visitors made directly influenced their behavior, causing the whispers to express less behavior, becoming inert or hiding. It can be said that, with the insertion of enrichment, the female (Tronchinha) only interacted with the boxes after being relocated during the study to a new isolated area from the visitation, finally showing social behaviors of play that were not previously seen in the enclosure. with visualization of the public, demonstrating that the visitation was harmful to their well-being.

Males, on the other hand, actively explored the olfactory boxes, carrying out foraging, but they did not open or feed them, only after a few weeks of study that they were comfortable and opened the boxes to feed and play. This behavior shows that the species tends to be shy and fearful during the day, in addition to feeling intimidated by visiting, observing the public and managing enrichment, avoiding new activities. However, after feeling comfortable, social behaviors of playing with the boxes were observed, in addition to always exploring the enclosure and boxes olfactive. 


\section{Conclusion}

- The use of food and cognitive enrichment in large cats in captivity reduced stress and stereotyped behaviors, thus improving well-being.

- The most observed stereotyped behaviors in cats were: pacing and excessive inactivity. Being typical behaviors of stress in captivity.

- Social behavior was observed in almost all cats, except the tiger Tigrão, demonstrating that the surprise box technique was efficient in stimulating the playfulness of cats, both alone and in couples, being well accepted by the animals, therefore, a proposal of enrichment that can be integrated more often with these animals.

- All felines responded to the enrichment stimuli, but soon after the withdrawal, all returned to their previous stress levels. Thus, showing the importance of constantly stimulating these animals in captivity is necessary, in order to avoid stereotyped behaviors and even the death of these animals due to accumulated stress.

- In addition to the poor stimulus enclosure, it was observed that the size of the enclosures was an observed problem that probably directly affects the behavior of all felines in the study, being an important point for analysis in future works on animals in zoos and a possible modernization of these enclosures for each animal.

- The reality of many zoos prevents frequent enrichments from being implemented, be they financial, managerial or the availability of trained and trained personnel for the job of maintaining a routine of stimulating animals.

- The Zoological Park of Goiânia urgently needs to evaluate the possibility of transferring to a larger area, with proposals for larger and more suitable enclosures for all animals, in addition to a review of the management of these animals in captivity, in order to avoid stress and low well-being.

- Furthermore, it is expected that more work like this will be carried out in zoos, that it be a routine application of $\mathrm{AE}$ in their programs for the management of animal's captive there, so that we understand more how these animals behave.

\section{Acknowledgement}

I am grateful to PUC Goiás for the opportunity to study, I am grateful for the scholarship offered by the university and CAPES that enabled the realization of the master's degree and the project. I thank the Zoo of Goiânia and all the professionals of the institution. 
Azevedo CS, Barçante L (2018). Enriquecimento ambiental em zoológicos brasileiros: em busca do bem-estar animal. Zoociências 19 (2): pag.15-34.

Babb, M (2020). Behavioural Comparison of Cougars (Puma Concolor) and Lions (Panthera Leo) Between Zoo and Sanctuary. https://doi.org/10.17615/ksqn-qw63.

Basset, H.M. Buchanan, S (2007). / Applied Animal Behaviour Science 102, pag. 223245.

Barreto KFB; Guimarães CRP; Oliveira, ISS (2009). O zoológico como recurso didático para a prática de Educação Ambiental. Revista FACED, Salvador, n.15, 80p., Jan./jul.

Bell, CE (2001) Encyclopedia of the world's zoos. Chicago: Fitzroy Dearborn Publishers. v.3 P. 1556.

Bradshaw, J; Cameron-Beaumont, C (2000). The signaling repertoire of the domestic cat and its undomesticated relatives. The Domestic Cat: The Biology of Its Behaviour. 67-94.

Brenton, G; Barrot, S (2014). Influence of enclosure size on the distances covered and paced by captive tigers (Panthera tigris). Appl. Anim. Behav. Sci. 154: 66-75.

Broo, DM (1986) Indicators of poor welfare. British Veterinary Journal, London, v.142, p.524-526.

Broom, DM (1988) The scientific assessment of animal welfare. Applied Animal Behaviour Science, Amsterdam, v.20, p.5-19.

Broom, DM (1991a) Animal welfare: concepts and measurements. Journal of Animal science, Savoy, v. 69, p. 4167-4175.

Broom, DM (1991 b). Assessing welfare and suffering. Behavioral Processes, [s.1.], v. 25, n. 2-3, p.117-123, December. Elsevier BV.

Broom, DM (2008). Welfare Assessment and Relevant Ethical Decisions: Key Concepts. Annual Review of Biomedical Sciences, UNESP - Universidade Estadual Paulista. [s.1.], v. 10, p.79-90, 1 fev.

Broom, DM; Molento, CM (2004) Animal welfare: concept and related issues. Archives of Veterinary Science. Curitiba, p. 1-11. fev.

Broom, DM, Fraser, AF (2010) Comportamento e Bem-estar de Animais Domésticos. 4. Ed. São Paulo: Manole. 
Brown, JL (2011) Female reproductive cycles of wild female felids. Anim. Reprod. Sci. 124: $155-162$.

Cabanac, M (1979); Sensory Pleasure. The Quarterly Review of Biology, University of Chicago Press. [s.1.], v. 54, n. 1, p.1-. 29, mar.

Carvalho, I (2017). Educação ambiental: A formação do sujeito ecológico. São Paulo: Cortez, P. 256; 2017

Cavalcanti, S, Gese, E (2009). Spatial Ecology and Social Interactions of Jaguars (Panthera onca) in the Southern Pantanal, Brazil. Journal of Mammalogy. Pag. 90.

Chanchani, P, Gerber, BD, Noon, BR (2018). Elevated potential for intraspecific competition in territorial carnivores occupying fragmented landscapes. Biological Conservation, 227, 275-283. doi: 10.1016/j.biocon.2018.08.017. 2018.

Clayton, S; Fraser, J; Saunders, CD (2008). Zoo experiences: conversations, connections, and concern for animals. Zoo Biology, v. 28, p. 377-397.

Clubb, R; Mason, G (2003). Animal Welfare: Captivity effects on wide-ranging carnivores. Nature. 425. 473-4.

Clubb, R; Mason. G (2007) Natural behavioral biology as a risk factor in carnivore welfare: How analyzing species differences could help zoos improve enclosures. Applied Animal Behaviour Science - APPLY ANIMAL BEHAVIOUR SCI. 102. P. 303328.

Coe, JC (1987). What's the Message? Exhibit Design for Education. In AMERICAN ASSOCIATION OF ZOOLOGICAL PARKS AND AQUARIUMS REGIONAL CONFERENCE PROCEEDINGS, Wheeling. Anais do American Association of Zoological Parks and Aquariums, Regional Conference Proceedings.

Costa, E (2014). Nutrição de Animais Selvagens Sob Cuidados Humanos. Minicurso. Costa, MJR; Pinto, A (2003); Princípios de etologia aplicados ao bem-estar animal.

Crashaw, PG; Quigley, HB (1991). Jaguar spacing, activity and habitat use in a seasonally flooded environment in Brazil. Journal of Zoology 223(3): 357-370.

Dias, JL (2003). Zoológicos e a pesquisa científica. Instituto Biológico, São Paulo, v. 65 , ed. $1 / 2$, p. $127-128$.

Dominguez, NT (2008). Enriquecimento ambiental em zoológicos, Fauna Brasil. Disponível em: http://www.faunabrasil.com.br.

Duncan, IJH (1993). Welfare is to do with what animals feel. Journal of Agricultural and Environmental Ethics.

Dunston, EJ.; Abell, J; Doyle, R. E.; Duffy, D; Poynter, C; Kirk, J; Hilley, V B; Forsyth, A; Jenkins, E.; Mcallister, D. (2017); Does captivity influence territorial and hunting 
behavior? Assessment for an ex situ reintroduction program of African lions Panthera leo. Mammal Review, [s.1.], v. 47, n. 4, p.254-260, 4 set.

Dutta, T (2005). Visitor profile at Peshwe Zoo, Maharashtra. Zoo's Print, v. 10, n. 8, p.13-16.

Estes, R (1991); The Behavior Guide to African Mammals: Including Hoofed Mammals, Carnivores, and Primates. California: University of California Press. p. 611.

Ewer, RF (1998). The Carnivores. Ithaca: Cornell University Press. 500 p.

Falk, J; Heimlich, J; Bronnenkat, K (2008). Using identity-related visit motivations as a tool for understanding adult zoo and aquarium visitors' meaning-making. Curator, v. 51, n. 1 , p. 55-79.

Frajblat, M; Langaro, VLA; Rivera, EAB (2008). Ciência em animais de laboratório. Ciência e Cultura, v.60, n.2, p.44-46.

Frajblat, M; Amaral, VLL; Rivera, AB (2006) Bem-estar em Animais de Laboratório. In: Rogerio Christofoletti e Alfeu Antônio Hausen Beck. (Org.). Ética, Ciência e Desenvolvimento. Itajaí: Editora da Universidade do Vale do Itajaí, p. 117-128.

Fraser, D (2008).; Understanding Animal Welfare: The Science in its Cultural Context. Chichester: Wiley Blackwell.

Funston, P (2011). Population Characteristics of Lions (Panthera leo) in the Kgalagadi Transfrontier Park. South African Journal of Wildlife Research. 41. 1-10.

Goodrich, JM (2010). Tiger conservation in the Year of the Tiger. Integrative Zoology, [s.1.], v. 5, n. 4, p.283-284, dez.

Gomes, MAS. (2013). Os Parques e a Produção do Espaço Urbano. Jundiaí, Paco Editorial.

Gonçalves, MAB, Da Silva, SL, Tavares, MCH, Gorsmann, NV, Cupreste, CF, Di Castro, PHG (2010). Comportamento e bem-estar animal: o Enriquecimento Ambiental. In Andrade, A., Andrade, M.C.R., Marinho, A. M., \& Ferreira Filho, J. Biologia, Manejo e Medicina de Primatas não humanos na Pesquisa Biomédica. (Cap.5). Rio de Janeiro: Ed. Fiocruz.

Gonzáles, A; Moncada, JA; Aranguren, J (2009). Los visitantes del Parque Zoológico y Botánico Bararida, Estado Lara: demanda real e implicaciones educativas ambientales. Investigación y Postgrado, v. 24, n. 3, p. 213-238.

Hargrove, E (1995). The role of zoos in the twenty-first century. In: Norton, B.G.; Hutchins, M.; Stevens, E.F.; Maple, T.L. (Eds.). Ethics on the ark: zoos, animal are welfare, and wildlife conservation. Washington: Smithsonian Institute Press, P.13-20.

Hayward, M.; Jerdzejewski, W; Jedrezejewska (2012), B. Prey preferences of the tiger. Journal of Zoology. p.221-231. 
Hollingsworth (2003). Panthera tigris. Disponível em: https://upload.wikimedia.org/wikipedia/commons/4/49/Panthera_tigris_tigris.jpg.

Hötzel, MJ; Machado Filho, LCP (2002). Bem-estar dos suínos.

Hugues, BO; Duncan, IJH (1988). The notion of ethological "need", models of motivation and animal welfare. Animal Behavior, v.36, p. 1696-707.

Independent, (2020) Pandas mate for first time in 10 years after coronavirus shuts down zoo. Disponível em: https://www.independent.co.uk/news/world/asia/pandascoronavirus-mating-baby-breeding-ocean-park-zoo-hong-kong-a9453976.html.

Karantjh; Nichols (2010). Non-invasive Survey Methods for Assessing Tiger Populations. Tigers of the World, pp.241-261.

Kitchener, A (1991). The natural history of the wild cats / Andrew Kitchener. Serbiula (sistema Librum 2.0).

Kisling, VN (2001). History: earliest zoos to present days. In: BELL, C.E. (Ed.). Encyclopedia of the world's zoos. Chicago: Fitzroy Dearborn Publishers, P.556-570.

Kotze, R (2018). The influence of social and environmental factors on organization of African lion (Panthera leo) prides in the Okavango Delta. Journal of Mammalogy. South Africa, p. 845-858. 10 jul.

Leyhausen, P (1979). Cat Behavior: The Predatory and Social Behavior of Domestic and Wild Cats. England: Taylor \& Francis / Garland Stpm Press.

Lindzey, FG (1987). Mountain lion. Wild furbearer management and conservation in North America. Ontario Ministry of Natural Resources, Toronto, pp. 656-668.

Lossa, G (2009). Are wild animals suited to a travelling circus life? Animal Welfare. 18: 129 - 140.of Agricultural and Environmental Ethics 6(2): 8-14.

Macdonald, D; Loveridge, A (2010). The Biology and Conservation of Wild Felids. Oxford: Oxford University Press, 784 p.

Macdonald, D (1992). The Velvet Claw: A Natural History of the Carnivores. Londres: BBC Books, 256 p.

Meena, V; Macdonald, D; Montgomery, R (2014). Managing success: Asiatic lion conservation, interface problems and peoples' perceptions in the Gir Protected Area. Biological Conservation. 174. 120-126.

Maia, CM (2009). Comportamento de Onça-Parda (Puma concolor), no Zoológico de Campinas, frente à visitação pública. 2009. $41 \mathrm{f}$. Tese (Doutorado) - Curso de Ciências Biológicas, Unesp, São Paulo, 2009. Disponível em: https://repositorio.unesp.br/bitstream/handle/11449/119764/maia_cm_tcc_bot.pdf?sequ ence $=1$. 
Moncada, JA; Aranguren, J.; Díaz, E; Castill, MDEL; Benaya, J (2002). Implicaciones prácticas de las preferencias de los visitantes del Parque Zoológico Caricuao, Caracas. Investigación y Postgrado, Caracas, v. 17, n. 1, p. 135-158.

Morales, LM (2003). A segregação planejada: Goiânia, Brasília e Palmas. $2^{a}$ edição. Goiânia: Ed. da UCG.

Morgan, JM; Hodgkinson, M (1999). The motivation and social orientation of visitors attending a contemporary zoological park. Environment and Behavior, v. 31, n. 2, p.227-239.

Myers, OE; Saunders, CD; Birjulin, AA (2004). Emotional dimensions of watching zoo animals: An experience sampling study building on insights from psychology. Curator: The Museum Journal, v. 47, n. 3, p. 299-321.

Nowell, K; Jackson, P (1996). North Africa and Southwest Asia, Cheetah. Wild cats: Status survey and conservation action plan. Gland, Switzerland: IUCN/SSC Cat Specialist Group; p 41-44.

Núñez, R, Miller, B, Lindzey, F (2002). Ecología del jaguar en la reserva de la biosfera de chamela-cuixmala, jalisco, México. In: (Eds.), El Jaguar En El Nuevo Milenio. Fondo de Cultura Económica, Universidad Nacional Autónoma de México, Wildlife Conservation Society, México D.F, pp. 99-118.

Onça-pintada, I (2020). Comportamento da Onça-Pintada. 2019. Disponível em: http://jaguar.org.br/comportamento/.

Oliveira, G; Bruck, M; Veronez, T (2018). Breve histórico do uso de enriquecimento ambiental. In: ENRIQUECIMENTO Ambiental: Qual a melhor forma de utilização do Enriquecimento Ambiental para camundongos em biotério. [S. $l .: s$. $n$.], ISBN: 978-855522-322-8. E-book.

Ottoson, D (1983). Physiology of the Nervous System. London: The Macmillan Press Ltd.

Panskepp, J (1998). Affective Neuroscience. The Foundation of Human and Animal Emotion. New York: O.U.P.

Pluck, K (2004). Panthera leo. Disponível em: By Kevin Pluck - Flickr: The King., CC BY 2.0, https://commons. wikimedia.org/w/index.php?curid=755560.

Podturkin, A (2020). Development of an environmental enrichment programme: A case study with a white Bengal tiger (Panthera tigris bengalensis) and a jaguar (Panthera onca) at Moscow Zoo. Journal of Zoo and Aquarium Research. Moscow, p. 1-7. 30 maio.

Reade, LS.; Waran, NK (1996). The modern zoo: How do people perceive zoo animals? Applied Animal Behaviour Science, v. 47, p. 109-118.

Saad, CEP, Saad, FM de OB.; França, J (2011). Bem-estar em animais de zoológicos. 
Revista Brasileira de Zootecnia, Uberlândia, v. 40, n. 1, p. 38-43.

Silva, RO (2011). Enriquecimento ambiental cognitivo e sensorial para onçaspintadas (Panthera onca) sedentária sem cativeiro induzindo redução de níveis de cortisol promovendo bem-estar. 71 f. Dissertação (Mestrado) - Curso de Psicologia, Departamento de Processos Psicológicos Básicos, Universidade de Brasília, Brasília.

Stanton, LA; Sullican, MS; Fazio, JM (2015). A Standardized Ethogram for the Felidae: A Tool for Behavioral Researchers, Applied Animal Behaviour Science, 1.

Scognamillo, D; Maxit, IE, Sunsquist; M; Polisar, J (2003). Coexistence of jaguar (Panthera onca) and puma (Puma concolor) in a mosaic landscape in the Venezuelan llanos. Journal of Zoology 259(03): 269-279.

Seymour, KL (1989). Panthera onca (Linnaeus, 1758). Mammalian Species, Lawrence, n. 340, p. 1-9.

Shoemaker, AH; Maruska, EJ., Rockwell, R (1997). Minimum Husbandry Guidelines for Mammals: Large Felids. American Association of Zoos and Aquariums, New York.

Skibins, JC; Powell, RB (2013). Conservation caring: measuring the influence of zoo visitors' connection to wildlife on pro-conservation behaviors. Zoo Biol. 32: 528-540.

Sunsquit, M; Sunquist, F (2002). Wild Cats of the World. University of Chicago Press, Chicago. 2002.

Swank, W; Teer, J. (1987). Status of the jaguar - Oryx 23: 14-21.

Tirelli, F (2009). Felídeos do RS: Panthera onca. Panthera onca. 2019. Disponível em: https://www.ufrgs.br/faunadigitalrs/wp-content/uploads/2019/07/cartilhaFel\%C3\%ADdeos-RS-1.pdf.

Vasconcelos, ASO (2009); Estímulo ao forrageamento como fator de enriquecimento ambiental para lobos guarás: efeitos comportamentais e hormonais. 2009. Tese (Doutorado em Psicologia Experimental) - Instituto de Psicologia, Universidade de São Paulo, São Paulo.

Veasey, JS.; Waran, NK; Young, RJ (1996) On comparing the behavior of zoo housed animals with wild conspecifics as a welfare indicator. University of Edinburgh: [s.n.], $12 \mathrm{p}$.

Veroneze, AS, Fernandes, DR; Almeida, HS; Silva, ELF; Borlini, TC (2020). Enriquecimento ambiental aplicado a tigres (Panthera tigris) e onças pintadas (Panthera onca) cativos no zoológico Zoo Park da Montanha - Marechal Floriano ES. Atas de Saúde Ambiental (São Paulo, online), ISSN: 2357-7614 - Vol. 8, p. 110-121.

Wemmer, CM; Scow, K (1977). Communication in the Felidae. In Sebeok, p. 110-121.

West, PM; Packer, C (2013). Panthera leo. Pages 149-159 in Kingdom J, Hoffmann M, editors. The Mammals of Africa, Volume V: Carnivores, Pangolins, Equids and 
Rhinoceroses. Bloomsbury Publishing, London, UK. Welfare Framework for Zoos, Journal of Applied Animal Welfare Science, 18:sup1, S1-S10.

Young, RJ (2003). Environmental Enrichment for Captive Animals. Oxford, WileyBlackwell, 240p. 


\section{TABLES}

Table 1. Result of the evolution of behaviors before, during and after environmental enrichment.

\begin{tabular}{|c|c|c|c|c|c|}
\hline & \multicolumn{3}{|c|}{ Environmental Enrichment } & \multirow{2}{*}{$z$} & \multirow{2}{*}{$p^{*}$} \\
\hline & Before & During & After & & \\
\hline \multicolumn{6}{|c|}{ Panthera leo } \\
\hline RP & $2,38 \pm 2,36$ & $1,75 \pm 1,69$ & $1,31 \pm 1,78$ & 1,68 & 0,43 \\
\hline $\mathrm{V}$ & $0,38 \pm 0,89$ & $0,44 \pm 0,51$ & $0,63 \pm 0,89$ & 2,00 & 0,37 \\
\hline EO & $0,25 \pm 0,45$ & $1,75 \pm 1,06$ & $0,81 \pm 0,83$ & 17,42 & $<0,001$ \\
\hline $\mathrm{D}$ & $0,00 \pm 0,00$ & $0,00 \pm 0,00$ & $0,13 \pm 0,34$ & 4,00 & 0,13 \\
\hline A & $0,06 \pm 0,25$ & $0,13 \pm 0,34$ & $0,00 \pm 0,00$ & 2,00 & 0,36 \\
\hline $\mathrm{S}$ & $0,00 \pm 0,00$ & $1,63 \pm 1,02$ & $0,00 \pm 0,00$ & 28,00 & $<0,001$ \\
\hline CE & $1,19 \pm 2,01$ & $1,00 \pm 1,63$ & $1,69 \pm 1,45$ & 2,31 & 0,31 \\
\hline $\mathrm{F}$ & $0,94 \pm 1,18$ & $1,75 \pm 1,00$ & $1,94 \pm 1,06$ & 4,36 & 0,11 \\
\hline \multicolumn{6}{|c|}{ Panthera onca } \\
\hline $\mathrm{RP}$ & $1,79 \pm 1,93$ & $0,96 \pm 1,40$ & $1,58 \pm 1,35$ & 3,54 & 0,17 \\
\hline $\mathrm{V}$ & $0,38 \pm 1,13$ & $0,00 \pm 0,00$ & $0,00 \pm 0,00$ & 6,00 & 0,05 \\
\hline EO & $0,75 \pm 1,48$ & $1,83 \pm 1,20$ & $1,63 \pm 1,10$ & 16,12 & $<0,001$ \\
\hline $\mathrm{D}$ & $0,29 \pm 0,55$ & $0,25 \pm 0,53$ & $0,21 \pm 0,41$ & 0,18 & 0,91 \\
\hline A & $0,00 \pm 0,00$ & $0,00 \pm 0,00$ & $0,13 \pm 0,34$ & 6,00 & 0,05 \\
\hline $\mathrm{S}$ & $0,25 \pm 0,53$ & $2,63 \pm 1,28$ & $0,42 \pm 0,65$ & 34,71 & $<0,001$ \\
\hline $\mathrm{CE}$ & $1,04 \pm 1,81$ & $0,29 \pm 0,86$ & $0,29 \pm 0,81$ & 8,38 & $\mathbf{0 , 0 1}$ \\
\hline $\mathrm{F}$ & $1,29 \pm 1,49$ & $2,38 \pm 0,92$ & $2,58 \pm 1,44$ & 11,73 & 0,003 \\
\hline \multicolumn{6}{|c|}{ Panthera tigris } \\
\hline RP & $1,41 \pm 2,05$ & $1,09 \pm 1,71$ & $1,00 \pm 1,24$ & 0,10 & 0,95 \\
\hline $\mathrm{V}$ & $0,06 \pm 0,25$ & $0,00 \pm 0,00$ & $0,03 \pm 0,18$ & 2,00 & 0,37 \\
\hline EO & $0,88 \pm 1,10$ & $1,50 \pm 1,19$ & $1,22 \pm 1,04$ & 3,55 & 0,17 \\
\hline $\mathrm{D}$ & $0,19 \pm 0,40$ & $0,25 \pm 0,67$ & $0,31 \pm 0,78$ & 0,05 & 0,97 \\
\hline A & $0,00 \pm 0,00$ & $0,00 \pm 0,00$ & $0,03 \pm 0,18$ & 2,00 & 0,36 \\
\hline $\mathrm{S}$ & $0,06 \pm 0,25$ & $0,75 \pm 0,95$ & $0,00 \pm 0,00$ & 26,00 & $<0,001$ \\
\hline $\mathrm{CE}$ & $1,22 \pm 1,60$ & $1,69 \pm 2,31$ & $1,09 \pm 1,63$ & 0,46 & 0,79 \\
\hline $\mathrm{F}$ & $1,44 \pm 1,52$ & $1,69 \pm 1,73$ & $2,56 \pm 1,48$ & 13,57 & $\mathbf{0 , 0 0 1}$ \\
\hline \multicolumn{6}{|c|}{ Puma concolor } \\
\hline RP & $2,29 \pm 2,39$ & $1,00 \pm 1,18$ & $1,79 \pm 1,53$ & 2,29 & 0,31 \\
\hline $\mathrm{V}$ & $0,00 \pm 0,00$ & $0,00 \pm 0,00$ & $0,00 \pm 0,00$ & \multicolumn{2}{|c|}{ na } \\
\hline EO & $0,50 \pm 0,93$ & $2,21 \pm 1,41$ & $1,33 \pm 1,09$ & 24,10 & $<0,001$ \\
\hline $\mathrm{D}$ & $0,04 \pm 0,20$ & $0,08 \pm 0,41$ & $0,08 \pm 0,41$ & 0,01 & 1,00 \\
\hline A & $0,00 \pm 0,00$ & $0,00 \pm 0,00$ & $0,00 \pm 0,00$ & \multicolumn{2}{|c|}{ na } \\
\hline $\mathrm{S}$ & $0,00 \pm 0,00$ & $0,54 \pm 0,98$ & $0,42 \pm 1,14$ & 7,40 & $\mathbf{0 , 0 2}$ \\
\hline $\mathrm{CE}$ & $0,33 \pm 1,01$ & $0,75 \pm 1,54$ & $0,00 \pm 0,00$ & 5,42 & 0,06 \\
\hline $\mathrm{F}$ & $1,42 \pm 1,44$ & $1,38 \pm 1,66$ & $1,83 \pm 1,17$ & 2,31 & 0,31 \\
\hline
\end{tabular}

*Friedman test followed by Nemenyi's Posthoc analysis represented by the letters 
Table 2. Description of the contribution of each variable to the canonical discriminant function analysis model.

\begin{tabular}{cc}
\hline & Discriminant function coefficients \\
\hline S & 0,84 \\
RP & 0,49 \\
CE & 0,49 \\
V & 0,41 \\
A & 0,32 \\
EO & 0,12 \\
F & 0,09 \\
D & 0,07 \\
\hline
\end{tabular}

*PR: rest / stopped, V: vocalization, EO: olfactory exploration, D: demarcation, A: agonism, S: social, CE: stereotyped behavior, F: physiological. 
Table 3. Result of the analysis of the factorial variance (ANOVA-Factorial) from a Generalized Linear Model (MLG) using social behavior as a response variable.

\begin{tabular}{cccccc} 
Source & $r^{2}$ & $\mathrm{gl}$ & $\begin{array}{c}\text { Medium } \\
\text { Square }\end{array}$ & $\mathrm{F}$ & $p$ \\
\hline Groups & & 3,00 & 10,94 & 19,94 & $<0,001$ \\
Environmental enrichment & 0,51 & 2,00 & 46,86 & 85,43 & $<0,001$ \\
Groups * Environmental enrichment & & 6,00 & 6,60 & 12,04 & $<0,001$ \\
\hline
\end{tabular}

Dependent variable: Social behavior 
Table 4. Result of the analysis of the factorial variance (ANOVA-Factorial) from a Generalized Linear Model (MLG) using the stereotyped behavior as a response variable.

\begin{tabular}{cccccc} 
Source & $r^{2}$ & $\mathrm{gl}$ & $\begin{array}{c}\text { Medium } \\
\text { Square }\end{array}$ & $\mathrm{F}$ & $p$ \\
\hline Groups & & 3,00 & 18,49 & 7,93 & 0,00 \\
Environmental enrichment & 0,11 & 2,00 & 0,88 & 0,38 & 0,69 \\
Groups * Environmental enrichment & & 6,00 & 3,67 & 1,57 & 0,16 \\
\hline Dependent variable: stereotyped behavior & & & & &
\end{tabular}


Table 5. Result of the analysis of the factorial variance (ANOVA-Factorial) from a Generalized Linear Model (MLG) using the rest / stopped behavior as the response variable.

\begin{tabular}{cccccc}
\hline Source & $r^{2}$ & $\mathrm{gl}$ & Medium Square & $\mathrm{F}$ & $p$ \\
\hline Groups & & 3,00 & 6,04 & 2,00 & 0,11 \\
Environmental enrichment & 0,06 & 2,00 & 14,03 & 4,65 & 0,01 \\
Groups * Environmental enrichment & & 6,00 & 2,37 & 0,79 & 0,58 \\
\hline
\end{tabular}

Dependent variable: rest / stopped behavior 


\section{FIGURES}

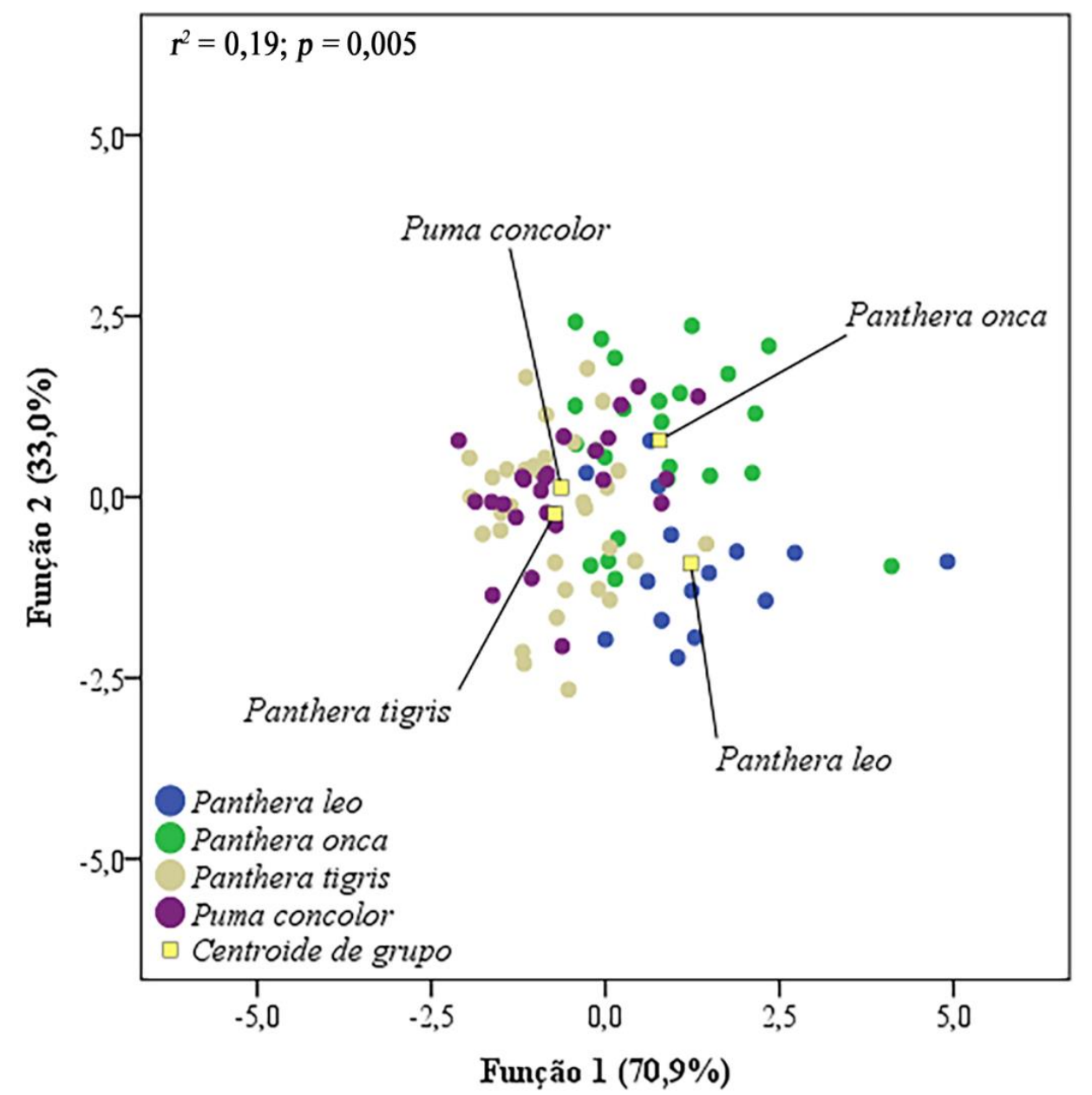

Figure 1. Scatter plot generated from the canonical discriminant function analysis scores.

Source: RANGEL, 2020. 


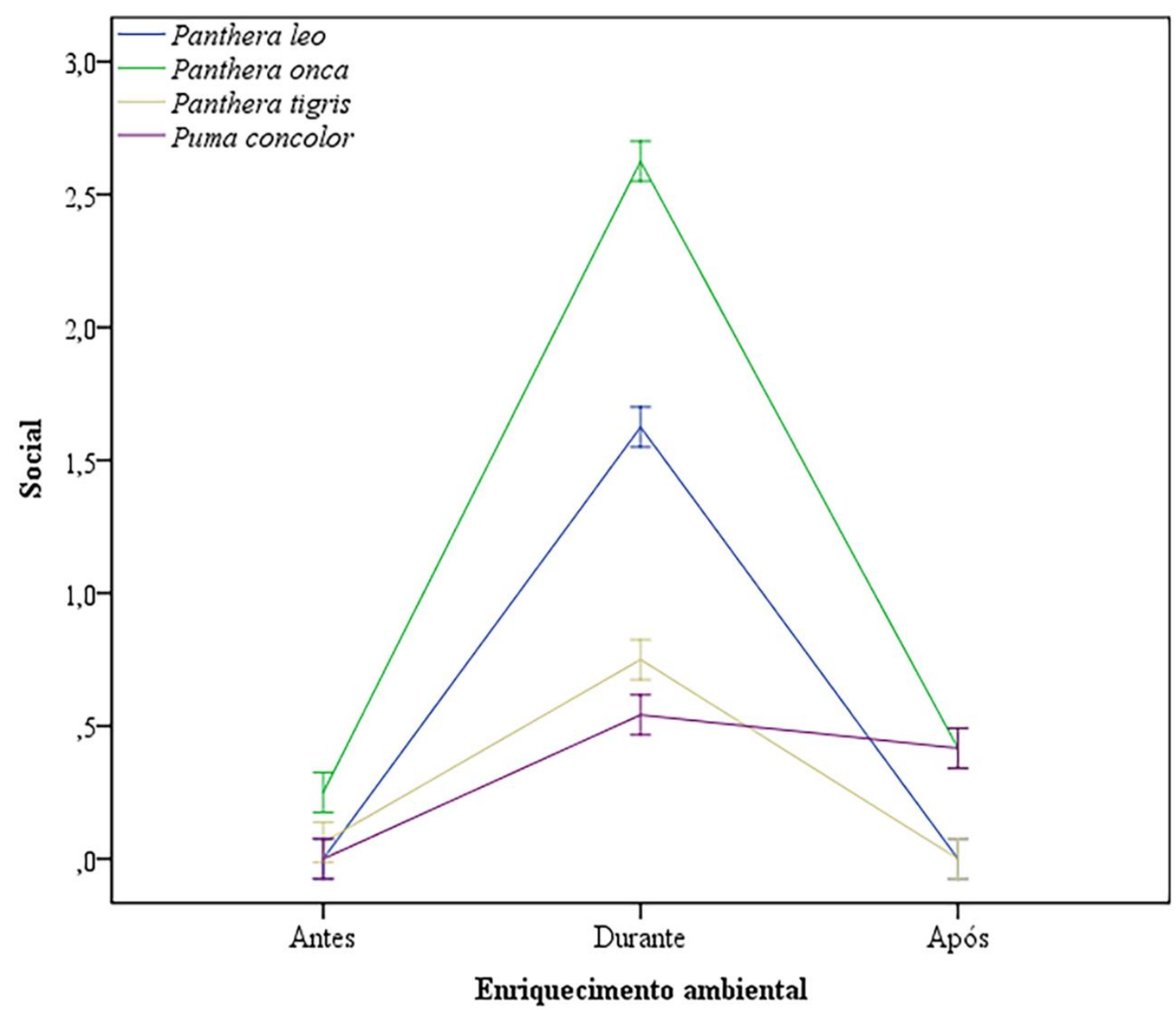

Figure 2. Social behavior before, during and after environmental enrichment in the four groups of cats in the PZG.

Source: Rangel, 2020. 


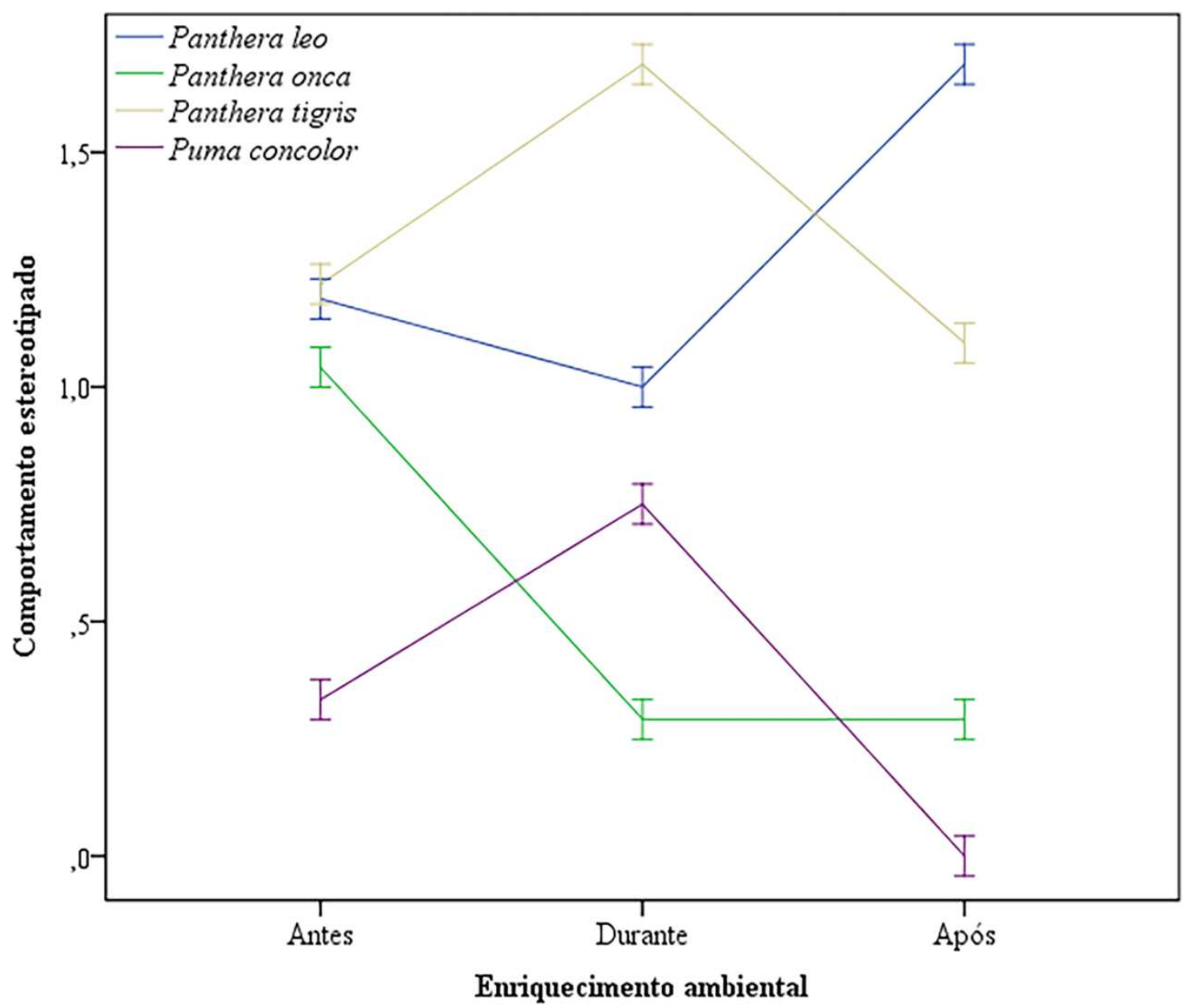

Figure 3. Line graph showing the result of stereotyped behavior before, during and after environmental enrichment in the four groups.

Source: RANGEL, 2020. 


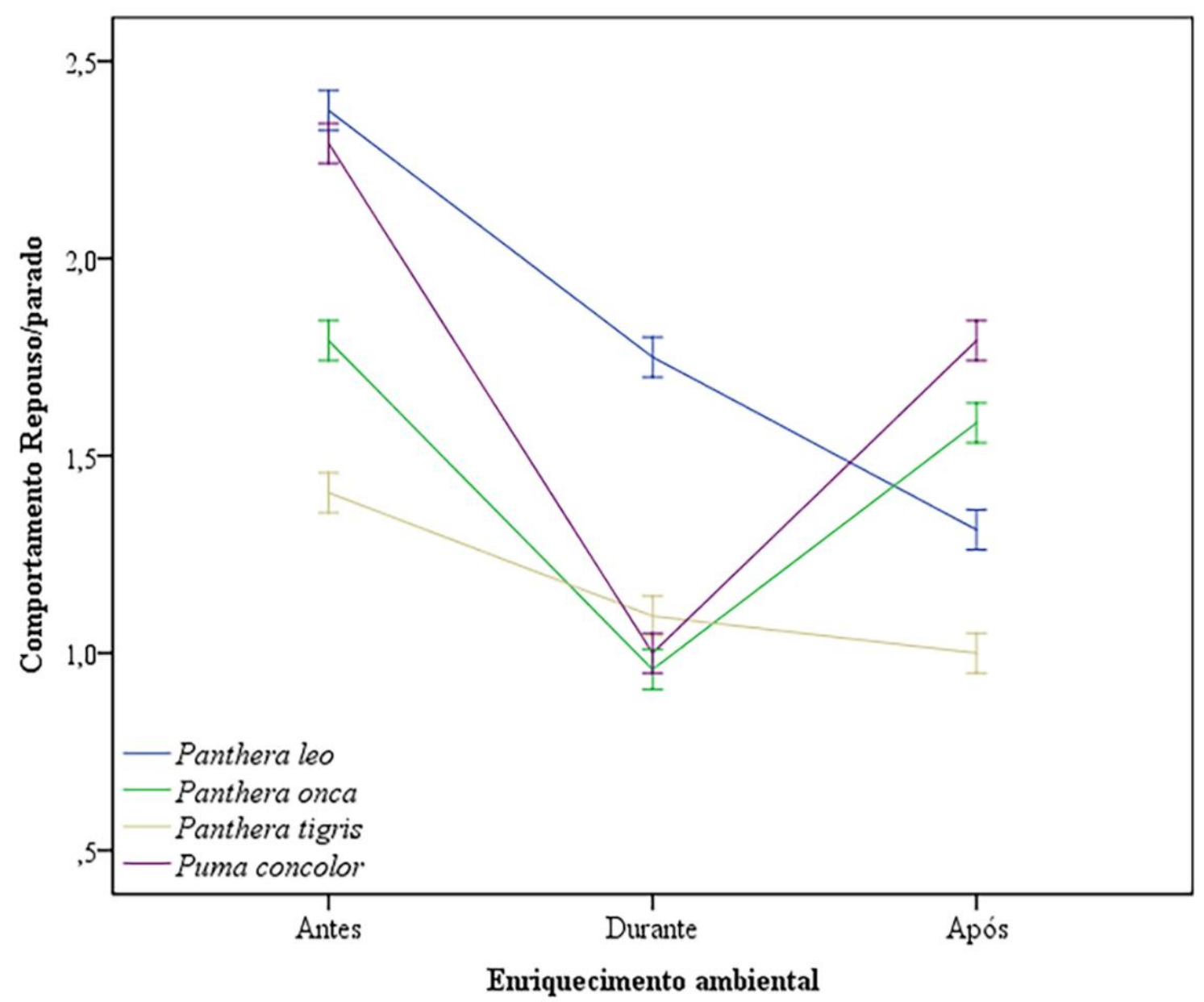

Figure 4. Line graph showing the result of rest / stopped behavior before, during and after environmental enrichment in the four groups.

Source: RANGEL, 2020. 
Figures

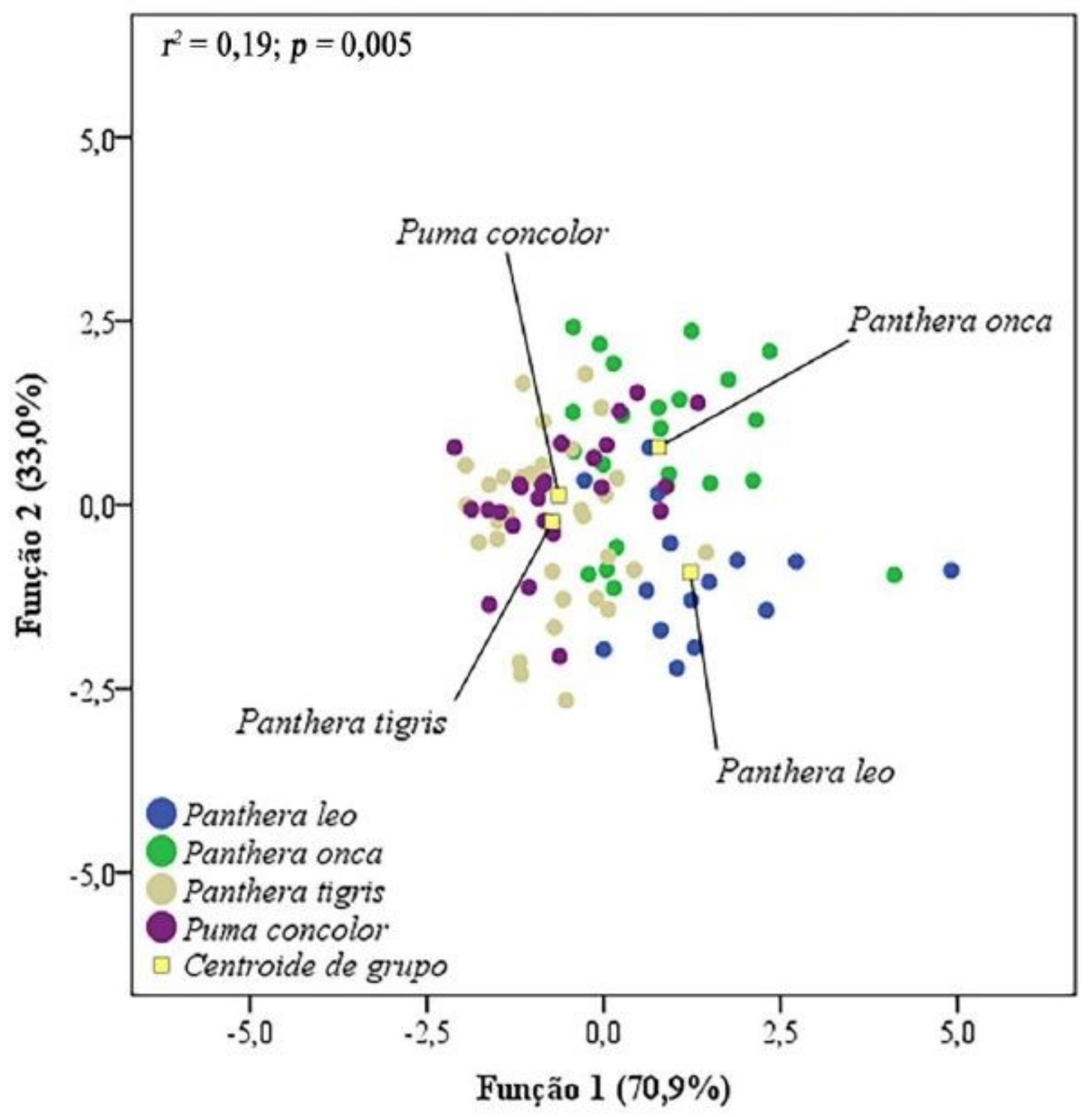

Figure 1

Scatter plot generated from the canonical discriminant function analysis scores. Source: RANGEL, 2020. 


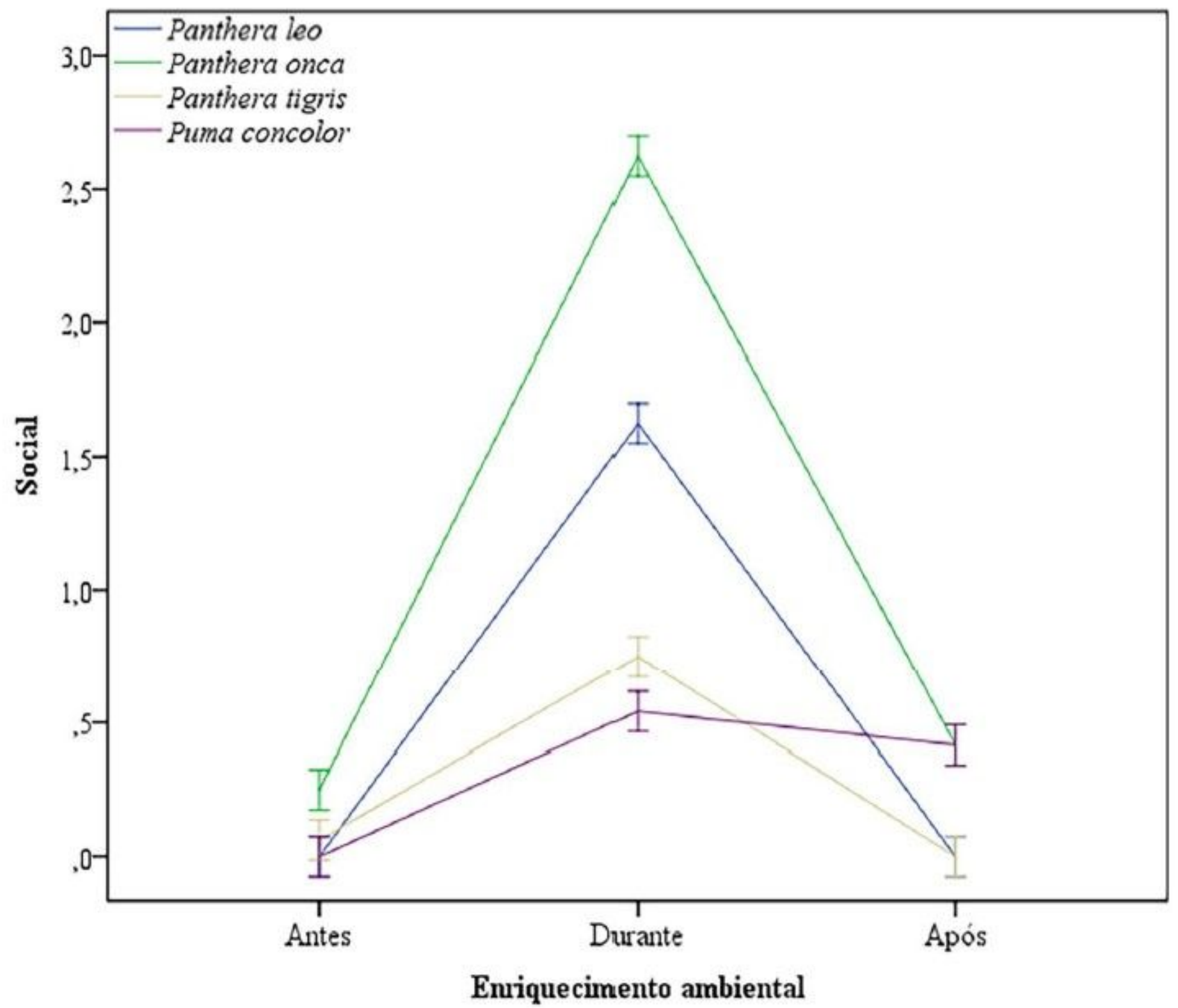

Figure 2

Social behavior before, during and after environmental enrichment in the four groups of felids in the PZG. Source: Rangel, 2020. 


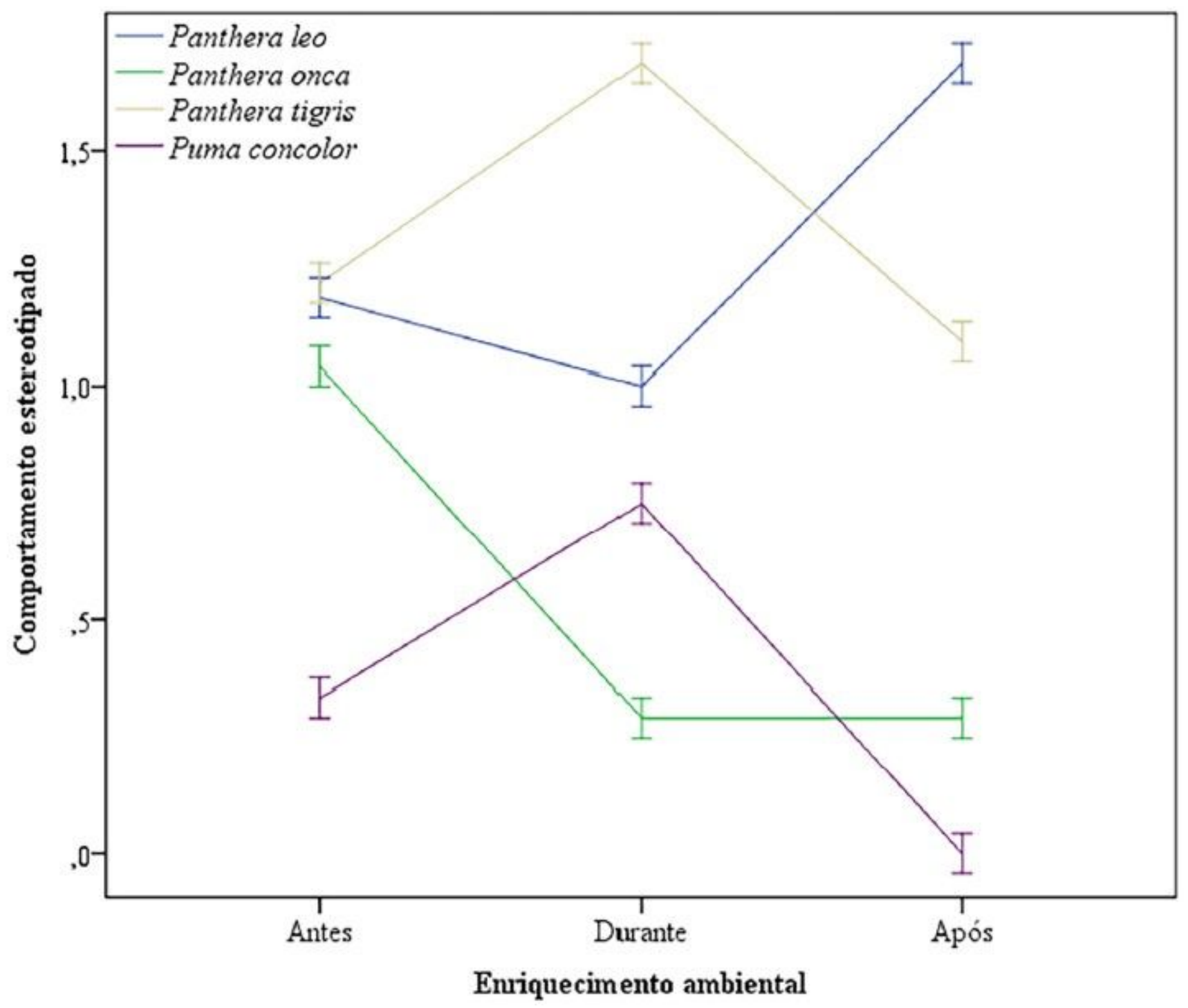

Figure 3

Line graph showing the result of stereotyped behavior before, during and after environmental enrichment in the four groups. Source: RANGEL, 2020. 


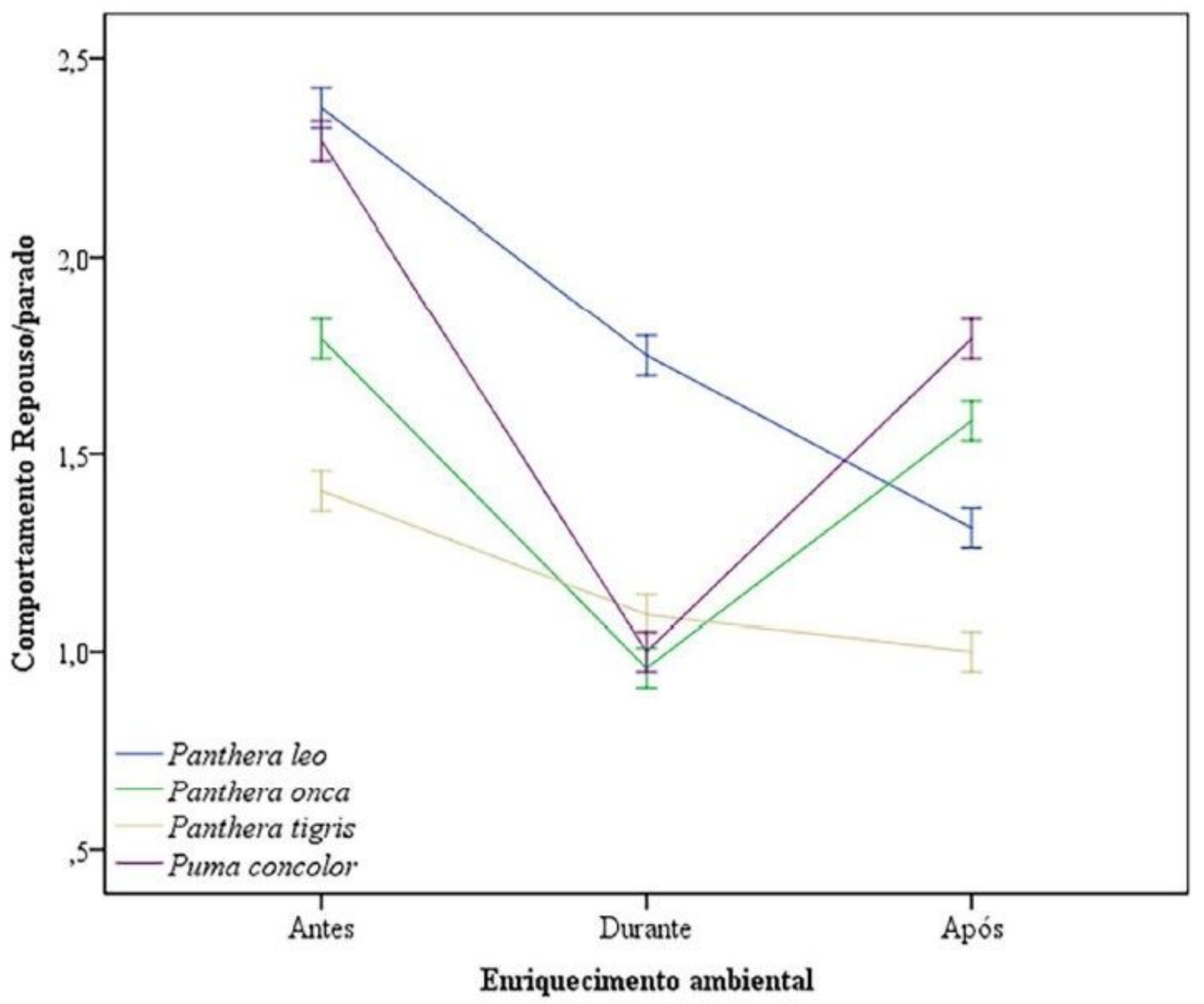

Figure 4

Line graph showing the result of rest / stopped behavior before, during and after environmental enrichment in the four groups. Source: RANGEL, 2020. 